Jarvis H. Community-led housing and 'slow' opposition to corporate development: citizen participation as common ground?. Geography Compass 2015, 9(4), 202-213.

\title{
Copyright:
}

This is the peer reviewed version of the following article: Jarvis $\mathrm{H}$. Community-led housing and 'slow' opposition to corporate development: citizen participation as common ground?. Geography Compass 2015, 9(4), 202-213. which has been published in final form at http://dx.doi.org/10.1111/gec3.12206. This article may be used for non-commercial purposes in accordance with Wiley Terms and Conditions for Self-Archiving.

DOI link to article:

http://dx.doi.org/10.1111/gec3.12206

Date deposited:

$28 / 05 / 2015$

Embargo release date:

15 April 2017

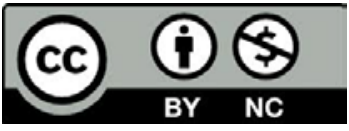

This work is licensed under a Creative Commons Attribution-NonCommercial 3.0 Unported License 


\section{Helen Jarvis}

\section{Newcastle University}

REVISED SUBMISSION to Compass (Social Geography) January 2015 PLEASE DO NOT QUOTE WITHOUT PERMISSION

\section{Community-led housing and 'slow' opposition to corporate development: citizen participation as common ground?}

\section{Introduction}

Recent years have witnessed renewed interest in the transfer of power to local citizens and community groups as a means to fulfil locally defined housing needs and aspirations. To appreciate what is in effect a popular as well as a political reengagement with 'procommunity' place-making (Power 2011: 45), we need to acknowledge general and specific trends of 'localism' that intersect with 'community-led' and 'slow' ideologies. Making these connections helps explain why these umbrella terms suggest a consensus of understanding that is in practice contested and differentiated.

The notion of 'localism' is evident on a number of intersecting geographic scales; as the currency of a groundswell of popular social movements seeking to reverse the decline of civic influence in local concerns; as a platform for issue-specific community-led development; and as the substance and rhetoric of national planning and housing policy frameworks. It is important to differentiate general from particular localism, especially with respect to planning and housing policy. In the UK, for instance, opportunities for community and non-profit housing vary across four different jurisdictions of devolved policy-makingEngland, Wales, Scotland and Northern Ireland (see Maclennan and O'Sulivan 2013). 
Internationally, academic debate highlights a trend of political restructuring described as 'new localism' that is common to neoliberal regimes in the UK, USA and Australia (Harvey 2005; Argent 2005). In many respects there is nothing 'new' about national governments restructuring political regulation of the market to emphasise local decision-making and community assets (Clapham and Kintrea 2000: 538; Wyler 2009). Indeed, localism represents an enduring political ideology that appeals to both the left and right of the political spectrum (Moore and McKee 2014). Yet, what we are now witnessing is the reinvention of local authorities as enabling authorities whereby government gives way to governance and emphasis shifts to flexibility, enterprise and partnership (Cochrane 2007; Amin 2005). Spatial and historical discontinuities highlight the paradox of localism that is variously instrumental and involuntary. This is evident in the way that community groups and projects are expected to replace state welfare functions as reserve 'capacity' to fall back on at a time of austerity (Elwood 2004). In the Australian context, Argent (2005) describes this as a "neoliberal seduction'. On the one hand the spatiality of localism is inherently attractive to rally popular support through 'proximity, co-presence and reach'. On the other hand, when public spending is cut, communities are often forced into driving local development as a kind of ‘mopping up' exercise (Argent 2005: 37).

This paradox is evident in the UK Big Society agenda, introduced since the coalition between the Conservatives and Liberal Democrats was announced on $11^{\text {th }}$ May 2010. This agenda combines a broad vision of citizen empowerment and local self-government alongside measures to address the UK's budget deficit and the cuts in public services deemed necessary as part of an 'era of austerity' (Lowndes and Pratchett 2012). Inconsistencies arise from efforts to deliver "small state localism alongside Big Society activism" that explain why the 
language of community-led development can be deemed both nebulous and contentious (Lowndes and Pratchett 2012: 22). This is especially true for housing and planning reforms that apply mainly to England where the 2011 Localism Act has deployed the concept of localism to decrease regulation, reduce local authority decision-making and intensify marketbased mechanisms (Jacobs and Manzi 2012: 42). Conditions are different in Wales, Northern Ireland and in Scotland where land reform is high on the political agenda (Riddoch 2011).

Renewed engagement with the political ideology of localism has raised the profile of community-led development in England as well as in the USA and Australia (DCLG 2011; Argent 2005). This umbrella term encompasses a number of sectors, including communityled housing (CLH), alongside social enterprise, local services and skills development, typically linked to community ownership and management of threatened local amenities such as shops, libraries, pubs and parks. Devolving power downwards offers an antidote to 'the sense of powerlessness around planning at the local level' in which decisions appear to be made at a distance by actors and institutions that do not understand or represent local concerns (Locality 2011). It suggests a way for local communities to retain the benefits of regeneration and development in their immediate locality. These conditions have inspired a proliferation of community activists, groups and projects to engage in civil society initiatives, many organized around locally defined housing.

The CLH sector is diverse and difficult to characterise. A wide range of models and approaches broadly fit the definition of 'homes that are developed and/or managed by local people or residents in not for private profit organisational structures' (Gooding 2013). They include community land trusts, development trusts, mutual and co-operative housing, cohousing and self-build. This diverse composition prevents scholars and practitioners 
arriving at commonly agreed terms and definitions. At the same time, it suggests a wealth of innovation and lessons to be learned for potential sector growth. Growth in the sector is one argument for closer academic scrutiny of CLH. Another is that England is significantly under-performing relative to other countries, including Scotland where a far greater proportion of social housing is community-led (CCMH 2009; McKee 2009).

Coinciding with a political framing of new localism is widespread popular re-engagement with a local sense of belonging at a convivial scale of civic engagement in particular towns and cities. This is evident in a number of new social movements similarly embracing the proximity and ideology of 'slow' to challenge the homogenizing effects of corporate development that appear to threaten a cherished local identity and way of life (Carp 2011). Since the late 1980s, the 'slow' moniker has been applied to food, fashion, housing and democracy, alongside more holistic place-based quality of life and sustainability initiatives. A common denominator is that 'slow' has come to mean local, not in a parochial sense but rather as a celebration of the "unique flavour that the soils and traditions of a place impart" (Clark and Teachout 2012: xxii).

One example is Cittaslow (pronounced "cheetah-slow") which is a worldwide network of over 175 towns and cities that have adopted a common set of goals and principles to enhance their quality of life (Radstrom 2011; UK Cittaslow Network). Cittaslow is usefully described as a place-specific, multi-faceted extension of the Slow Food movement which began in Italy in the late 1980s in response to what many perceived to be the negative health, social and economic impacts of "fast food" culture (Parkin and Craig 2006). Each Cittaslow town agrees to adopt a number of principles intended to foster economic, social and environmental sustainability. These are to encourage and celebrate diversity rather than standardisation; 
support and promote local culture and local traditions; work for a more sustainable environment; raise awareness and appreciation of local produce and local businesses; promote healthy eating and healthy living; and to work with the local community to build on these principles (Knox 2006; Miele 2008). The latter implies 'slow' democracy to cultivate "processes that are inclusive, deliberative and citizen powered" that "applaud a wide range of regional democratic practices" (Clark and Teachout 2012: xxii). Local diversity challenges the tendency for local 'best practice' to be rolled out, recognising instead the opportunities and constraints of place-based cultural context.

Curiously, while home and community are essential to a local sense of identity and belonging, there is little evidence of a practical connection being made between citizen-led quality of life initiatives and community-led housing, beyond the shared concern to promote civic engagement. Nevertheless, a 'slow housing' manifesto offers a relevant critique of the way standardised corporate development pervades "not only the way we build our homes and live in them, but also the way we buy and sell them" (Orsi 2011:1). The slow housing concept seeks to address specified local needs, where residents exercise direct involvement in opportunities to shape their immediate built environment and live in alignment with social and ecological values. It reflects what Amartya Sen defines as the 'freedom' to harness people's capacity to lead the kind of lives they value- and have reason to value (Evans 2002: 58). It describes alternative living arrangements that are stifled by mainstream market models of speculative housing. According to Heinonen et al. (2006), this ethos is not confined to 'material' aspects of living but rather linked to 'creative disruption' of dominant corporate and commercial lifestyle assumptions (Steele 2012, p.182). In effect, the slow housing manifesto chimes with goals that are enshrined in Cittaslow and CLH. 
The emerging discourse around 'new localism' suggests broad political, cultural and practical alignment around the positive connotations of community participation, including the idea that ordinary people should be able to build homes for themselves and for their community. It is broadly agreed that participation can summon forth new forms of citizenship that offer the potential for local residents to shape and influence housing and community development in socially progressive and sustainable ways. Yet, closer scrutiny of the relevant literature suggests that umbrella terms of 'localism' 'community-led' 'citizen participation' and 'slow' have resulted in fragmentation, and the absence of a clear agenda for integrated research and policy.

This paper draws particular attention to citizen involvement in creating new or modified forms of housing that are not available in the mainstream housing market. It does so by taking a view of CLH that looks beyond individual dwelling to the development of community facilities, a stronger sense of place identity, and support for local employment, schools and shops. Connections are made between a convivial scale of citizen participation in 'slow' quality of life social movements and new forms of citizenship associated with community-led housing. This highlights the socio-spatial 'architecture' underpinning citizen participation, and motivations that drive community-led housing from the bottom-up (author 2015). These need to be better conceptualised and understood if research and policy are to support and enable the process of growing locally driven housing solutions.

\section{New localism and community participation: by the people, for the people?}

In a key paper on participation, John Heron (1996) asks academics to carefully consider whether they are doing research with the public, rather than 'for' them or indeed 'on' them, as a subject. Similarly, the question who gets to build what, where, how- and why people feel 
motivated to co-create alternative housing solutions reflects the extent to which development is meaningfully citizen-led; whether citizens shape the neighbourhood and homes according to their own needs, or whether one community steers the development according to the anticipated needs of another. Participation is reasonably understood as a voluntary capacity. Arguably it is desirable to encourage a broad scope of community participation, but not all citizens want to be actively involved in local planning issues (London Tenants Federation 2014). For some people, participation is about 'having a say', by voting in a referendum or by attending public consultations on proposals in a neighbourhood plan. For some cohorts (such as young people, older people, those with special needs) the projects they are consulted on may appear to reproduce the same limited options that already exist. Thus what distinguishes participation from consultation is the possibility for an alternative outcome that would not otherwise have existed. In this sense the power of participation rests not only with the (unequal) capacity people have to shape their own environment and destiny but also through motivations and orientations, as suggested by utopian methods of thinking and imagining that other ways of living are possible (Levitas 2013).

Any attempt to categorise groups and projects in terms of who initiates and steers them risks creating false binaries that pitch one scale or form of participation as being more/ less legitimate. Yet, a neglected feature of civic engagement rests with the power imbalance between existing residents (who may or may not share a local sense of belonging and newcomers who may be excluded from mainstream housing options, motivated to participate in alternative CLH solutions. We need to consider not only the claims of the incumbent population but also those of would-be residents and future generations. Negotiating issues of participation and power as a function of stewardship also pertain to the social organisation and governance of individual CLH. In the literature on intentional communities, for instance, 
it is usual to distinguish between those 'forming' community, as pioneers or early adopters, and those 'finding' (or joining) an established community (Christian 2007, 163). On the one hand this acknowledges a huge debt owed to early adopters for their unpaid localism. On the other hand it disrupts the idea that promoting community participation is sufficient, "to encourage the inclusion of outsiders, to break down barriers created by wealth and privilege (or knowledge and motivation), or prevent those that are already better off and more dominant from flourishing at the expense of others" (Coote 2011: 85).

Two competing perspectives can be identified in the literature. A generally positive view suggests that the new localism opens up new spaces for democratic practice, specifically civil society initiatives, enabling more influential citizenship and participation in local decisionmaking processes (Healey 2007). Docherty et al. (2001) argue that effort devoted to civic initiatives that build confidence in the benefits of citizen participation is not wasted. The picture is more mixed for tenant participation in community-based social housing organisations where the suggestion is that without adequate public investment in housing conditions and repairs, tenants do not identify participation, empowerment and community ownership as key priorities (McKee 2009: 303). Tenants remain in a structurally weak position from which to imagine or co-create alternative living arrangements, through the degree of control on offer. Nevertheless, the Scottish experience of social housing stock transfer to community-based organisations suggests that the landlord-tenant power relationship can be reconstituted (Clapham and Kintrea 2000). Recent analysis in this field calls for a more nuanced understanding of the scope, scale and extent of citizen participation in community ownership of land and affordable housing within and between different parts of the UK (Moore and McKee 2014; Skerratt and Hall 2011; Moore and Mullins 2013). 
A negative view of new localism points to evidence that it "incorporates both neoliberal goals and emphasis upon citizen participation" arguing that this tension ultimately drives a contradictory emphasis on political expedience and the rapid delivery of housing over meaningful participation (Elwood 2004, p.760). Michael Ball (2004: 119) points to a number of ambiguities whereby public sector grants and subsidies call for community involvement but in a framework of participation which tends to reinforce rather than challenge existing coalitions of community representation. According to Ash Amin (2005), for active citizenship to be meaningful in community-led development it has to be 'without strings'. Rather than to emphasise involvement in management, he highlights a messier process_of empathetic 'sociality' with 'the potential to shift attitudes and behaviours through engagement' (Amin 2005: 628). We saw this above in 'slow' localism that seeks to cultivate diverse democratic practices. Accordingly, it may be that 'the sheer volume of civic activity should be seen as a gradual filling in of a democratic void' (Amin 2005: 628).

\section{Conceptualising CLH}

As noted above, the term community-led housing describes many different types of housing. As an umbrella term, it stands in opposition to speculative building for the open market and the large corporations or state entities that build and allocate housing in a remote fashion. This is what aligns CLH to a 'slow' ideology and concern to rescue the functional qualities of domestic architecture from globalised, standardised 'faceless sprawl'. A recurring theme is the notion of community empowerment, especially for tenants who are usually 'housed' by big corporation to a 'top down' assessment of need. Nevertheless, while community participation is a defining characteristic, citizenship functions on a continuum of modes and scales; from one citizen building their own home; through a self-organising group working together to create a neighbourhood with shared amenities, as with the cohousing concept; to 
citizen-led development trusts with a mandate to develop social housing for local residents as a non-profit organization.

A selection of CLH approaches are explained here specifically to highlight key social, material, legal, organisational and motivational distinctions that determine who gets to build what, where, how and why. This explains why cohousing is introduced as a discrete approach rather than the longer established mutual and co-operative model. While the socio-spatial concept underpin cohousing can be realised through a cooperative procurement model, the majority of mutual and co-operative housing function without the shared space and purposeful common amenities that distinguish cohousing.

\section{Self-build (self-help)}

The idea of ordinary people and community groups building homes for themselves is neither new nor unique to a particular place. When compared internationally, the UK has a historically weak self-build sector and it is a Government aspiration to double output over the next decade (Wallace et al. 2013). Self-help currently accounts for 8\% all new housing, compared with $50 \%$ or more in most other developed countries (NaSBA 2011: 2). While in the UK 'self-build' is typically associated with an educated middle class elite, building to their own preferences (Benson 2012), "self-help housing involves groups of local people bringing back into use empty properties that are in limbo" (BSHF 2010: 4).

The planning literature explains weak development in terms of the high financial cost of land acquisition and the red-tape associated with bringing land forward for development. Yet this does not explain the concentration of pioneer projects in particular regions long associated with a 'radical' politics or tradition of community engagement and transgressive social movements (Rigby 1974; Coates 2001). Neither does it explain why citizen-led housing has 
periodically flourished in the UK both inside and outside the housing market and conventional planning system (Hardy and Ward 1984; Benson 2014).

A simple definition of self-build housing is housing built by individuals or a group of individuals for their own use (NaSBA 2011, P.2). Yet, a recent typology of self-build in England highlights the paradox of a policy to promote innovative grassroots alternatives that fails to differentiate between private preference and group-work. The intention of the 2011 Housing Strategy was to signal greater opportunity for people to 'customise' their own home than is suggested by self-build as a marginal housing option. As a consequence this new blanket definition (custom build) subsumes cohousing, eco-villages, sweat equity models, community land trusts and social rented models (Wallace et al. 2013: 7). In practice, most self-build projects are purpose-made to the needs of an individual/household without reference to collaboration with other citizens, except in the process of acquiring planning permission and working with appointed contractors. At the same time, the Building and Social Housing Foundation claim that one in five self-builders are interested in building as part of a community of self-builders, rather than as a solo project (BSHF 2014). It is vital not to lose sight of the distinctions between what it takes to build a community as distinct from housing. Mullins (2010) differentiates 'custom build' from working-class traditions of community 'self-help'. While self-build housing involves constructing permanent homes from scratch, typically investing in innovative low-impact technologies, self-help offers a means to tackle dereliction and blight by drawing on community assets of 'sweat equity' (BSHF 2011). By providing skills and training in the process of building homes it suggests a holistic approach to housing and employment. This harks back to the community architecture movement that briefly surfaced in the 1980s which was motivated by passionate opposition to modern architecture and the power of remote experts and politicians (Wates and Knevitt 
1987). From this discussion it is suggested that the language of self-build needs to better reflect different degrees of citizen control and collective imagination and the impact this has on the possibility for alternative patterns of behaviour, technology, social organisation and community resilience.

\section{Cohousing}

Cohousing is a form of collective housing development in which residents actively participate in creating living environments that are not available in the mainstream market. Cohousing is not defined by its legal structure or by any idealised tenure: a group of 20 to 30 households will function as a non-profit association (whether as a cooperative or as a company limited by guarantee) while individual homes may be purchased for owner occupation or occupied through rental or intermediate leasehold arrangements (see Woodin et al. 2010). While the development process will involve elements of 'self-build' the actual building process is secondary to the socio-spatial concept itself. This combines shared with private spaces and amenities and it embeds self-managed governance structures in a deliberate attempt to increase purposeful interaction between neighbours. The concept is capable of adapting to different models of more/ less collective ownership and intentional values and it offers scope for cultural as well as social, economic and material innovation. For instance, Mattheiu Lietaert (2010) observes that cohousing is naturally allied to 'sustainable degrowth' because it establishes a holistic environment for learning about and enacting the behaviour changes necessary to reduce consumption and wage-based production.

The cohousing concept is inspired by Danish boflesskab (living-togetherness) and Swedish kollektivhus (collective housing) dating from the late 1960s (Vestbro 1992) but it captures the enduring ideals of a much longer communal imagination. Neighbours regularly sit down to 
eat meals that they prepare and eat together in a common house and this commitment to shared meals is widely held as the benchmark of shared cultural meaning and purpose (Meltzer 2005, p.8). Motives and characteristics of intention vary, but they typically address issues of social isolation and well-being, especially for an ageing population, and behaviour changes needed to reduce household energy consumption and waste and to support economic localisation (Field 2011).

International comparisons are complicated by the lack of clarity and consistency in the way common terms are used and translated (forthcoming 2014). In Germany, for instance, where there are an estimated 190,000 cooperative association apartments in Berlin alone, a large proportion of the cohousing builder collectives or Baugruppen represent partnerships between public bodies and voluntary and community sector organisations rather than the image often projected of an autonomous resident group (Ring 2013). Cohousing in Sweden is unusual not only for early adoption, but also because most schemes are built in urban areas at relatively high density and they are state-owned. In Denmark where close to 5\% of the population live in some form of community housing, the majority of cohousing projects have been built by private citizen groups, typically purchasing cheaper land in rural areas or small towns with good access to public transport. Recent developments in Scandinavia reflect ecoarchitectural innovations oriented to urban areas that are intended to tackle affordability and supportive neighbourhood arrangements for an ageing population (Lietaert 2010). In the UK, byy contrast, there are currently just 54 cohousing communities completed or under construction (Gulliver et al. 2013, p.25; UKCN 2014).

\section{Community land trusts}

Community Land Trusts (CLTs) are non-profit community-based organisations that are run by volunteers. They can be established to develop housing, workshops, community facilities 
or other assets, providing this is for the express purpose of furthering the social, economic and environmental interests of a local community, which is usually defined in relation to a geographic area. They can be established for the purpose of acquiring and managing land and other assets that provide benefit to the local community (Davis 2010). Although CLTs are relatively new in England they build on a long established history of community ownership and management of housing (such as in the Garden Cities that are based on a model where a community trust owns and manages the assets on behalf of the community) (Communitylandtrusts.org.uk 2014). They have flourished in Scotland over a longer history and rural communities have used new legislation to acquire land in perpetuity such as for the residents of Eigg who collectively set up the Isle of Eigg Trust to buy their island in 1997 (Moore and McKee 2012; Riddoch 2011).

The concept was first adopted in the USA in the late 1960s, influenced by a mix of American Indian ideas on stewardship of the commons and the civil rights movement (Moore and Mckee 2012, p.281). Since 2000 the number of CLTs has grown significantly in the USA (with an estimated 240 organisations and over 5,000 homes represented by this model). Growth has been similar internationally but it has been uneven across the UK reflecting legislative differences between the four jurisdictions. Recent growth recognises that CLTs offer a method of delivering affordable housing that empowers local communities and provides democratic management of community assets (Moore and Mckee 2012, p. 280). To create affordability a CLT needs to receive initial subsidy in one form or another; be it free land, or financial grants from government, charities or benefactors. A proportion of equity is retained by the CLT in order to try to suppress the resale price and ensure that the property remains affordable for the next buyer (Moore and McKee 2012: 281). In property law this is referred to as an 'asset lock'. This facility to limit property speculation to retain the benefits 
of regeneration for the local area and target clientele is fundamental to the CLT structure (Communitylandtrusts.org.uk 2014).

Conceptualising the process of 'slow' housing development The previous discussion suggests that a diverse array of citizen participation shapes the way that communities are crafted through action in the development process. Although it is reasonable to argue that civic participation in public life is a necessary condition of human flourishing, it is not sufficient as a way of transforming what is produced and how it is inhabited. For example, the process varies in the extent to which the design and build are undertaken 'by' or 'for' the occupants of the finished project. This distinction is illustrated in Figure 1 as a combined function of co-production, shared spaces for social interaction and the 'social architecture' of self-governance. Different outcomes are similarly suggested by comparing 'self-made' (custom built) and 'ready-made' development whereby citizen-led development trusts rarely deviate from conventional expectations of single family dwelling. This explains why it is not inevitable that community-led housing will look or function very differently from mainstream provision.

Figure 1 also illustrates the significance of competing motivations; such as to deliver affordable housing as social housing for local residents; and to deliver an ecological, affordable and community-based approach to construction (Chatterton 2013, p.1659). In the UK, public sector grants and subsidies have strict conditions attached that define affordability in terms of income and needs-based eligibility for housing assistance. Accepting public funding imposes restrictions on who can be housed there. This typically prevents prospective tenants from being involved in the design of the homes they go on to occupy. For a selfgoverning cohousing group, whether or not the group undertakes to build as a project of DIY or by working with a contractor, affordability tends to be limited to a modified or 
intermediate market model. In the Leeds-based project: Low Impact Living Affordable Community (Lilac) home ownership is decommodified to an extent within a Mutual Home Ownership Society affordability model (MHOS). This promotes access to less wealthy groups and discourages wealthier groups who are seeking speculative returns from housing, by dampening increases in resale values the property remains affordable from one generation to the next (Chatterton 2013, p.1665).

By exploring the process of participation for three discrete scale-types in Figure 1, it is possible to deconstruct social, spatial and stewardship aspects of empowerment. If this approach were to be extended, it would be possible to explain how collaborative design and build approaches benefit from 'economies of propinquity' in opposition to the orthodox assumption of an economy of scale. This perspective takes into account the motivations and impact of those involved. For example, there are critics who suggest that self-governing groups act from a narrow basis of self-interest, to provide their own housing. At the extreme, pejorative comparisons are made with common interest ('gated') communities (Chiodelli and Baglioni 2014). Yet there is more extensive evidence asserting positive claims of wider social benefit, with communities serving as living laboratories for 'learning, research and replicability' (Chatterton 2015: 175). Most cohousing communities have public spaces in which to organise regular workshops and their buildings are open to socio-technical performance evaluation. Building a robust evidence base from which to demonstrate claims of social benefit is one way for established CLH to help build momentum in the sector.

\section{Conclusions}

A local sense of belonging continues to matter to most people. This attachment crucially functions through the social, material and institutional structures of housing that determine 
'how and where' people live in relation to their neighbours and immediate environment. As Perkins and Thorns (2012, p.74) observe: "we all live somewhere, and a place to live allows us to connect with people, the wider community and natural environment": it is about making a home in a community of belonging. Yet, the literature suggests that very often, relationships between housing, place and community development are viewed in piecemeal fashion; worse still, when 'solutions' are applied to one piece of the puzzle (building more houses to address affordability) they can disrupt other key relationships.

The key point is that civic engagement in housing and neighbourhood planning should not be viewed as an end in itself, where 'having a say' is reduced to consultation simply to fulfil the requirements of a government funding application. Instead, a flourishing public life will open up multiple spaces for community organising and democracy. It takes time to cultivate cooperation and collaboration 'as a craft' that 'requires of people the skill of understanding and responding to one another in order to act together' (Sennett 2012, p.x). From this we discovered the 'slow' process of cultivating inclusion, deliberation and innovation. This is important because there is a risk in policy-making that one CLH model or approach will be favoured over another and taken out of context. Critics of neoliberal localism and advocates of slow housing similarly highlight the social benefits to be gained, in learning and innovation, from small-scale, diverse, grass roots interventions (BSHF 2014; O’Donovan and Rubbra 2012). Wendy Steele (2012) makes a similar point in relation to housing in Australia. She advances the ideology of slow housing as an antidote to perceived problems with local authorities simply 'scaling up' local affordable housing strategies in cities where affordable housing is in short supply. She calls for a continuum of alternative housing possibilities that either supplement or supplant the 'fast housing' status-quo in which economic growth, speed and efficiency displace equity (Steele 2012, p.184). 
A call for connections to be made between citizen-led quality of life initiatives and a politically motivated policy of increasing community-led housing and place-making is not simply a call for more 'joined up thinking'. Instead, integrated debate needs to highlight structural flaws in the wider housing and land markets and to challenge the neoliberal goals enshrined in the new localism. This resonates with arguments made elsewhere in human geography that emphasise the need for connectedness and interdependence based on 'mutual obligations and relations of trust' (McDowell 2004, p. 157), 'cooperation rather than competition' and 'interdependence over individuation' (Smith 2004, p.11).

It is tempting to conclude that any form of community-led development has a degree of citizen representation and thus capacity for community empowerment. However, it is evident from established public life studies that politicised forms of localism (stakeholder representation) do not equate with active participation by the people who will occupy and make sense of the places involved (Jacobs 1961; Alexander 1979; Whyte 1980). Despite a wealth of research literature and popular media interest in local participation in community housing and public life there remains much to be explained and understood in this disparate field. 


\begin{tabular}{|c|c|c|c|}
\hline Stage & Individual self-build (typically owner-occupier) & Group self-build (e.g. cohousing, various legal forms) & Citizen-led association (CLT or other corporate body) \\
\hline Stage one & $\begin{array}{l}\text { An individual/household imagines a particular home that does } \\
\text { not fit the ready-made market model. }\end{array}$ & $\begin{array}{l}\text { A few people get together (as 'burning souls') to discuss } \\
\text { inadequate ready-made housing/ their vision of building/living } \\
\text { together (may suggest social change). }\end{array}$ & $\begin{array}{l}\text { Local leaders representing a variety community interests } \\
\text { discuss local needs/ priorities; volunteers with a shared } \\
\text { ambition form a steering group. }\end{array}$ \\
\hline Stage two & $\begin{array}{l}\text { The project design is largely determined by personal assets } \\
\text { including building knowledge/skills and finance but also } \\
\text { influenced by sector guidance (e.g. National Custom \& Self } \\
\text { Build Association) and media inspiration. }\end{array}$ & $\begin{array}{l}\text { The group starts to develop its infrastructure (name, website, } \\
\text { trust and familiarity via business and social events shape } \\
\text { decision-making process/ governance); ends with formal } \\
\text { constitution (e.g. I \& P Cooperative). }\end{array}$ & $\begin{array}{l}\text { Regular steering group meetings establish volunteer } \\
\text { capacity/skills and willingness to develop housing for the } \\
\text { benefit of the wider community; ends with formal constitution } \\
\text { (e.g. Community Association or CLT). }\end{array}$ \\
\hline Stage three & $\begin{array}{l}\text { Finding a suitable site and financing a custom-build design are } \\
\text { major challenges; typically funded in part by sale of an existing } \\
\text { property; additional loans may be limited by perceived risk of } \\
\text { novel construction methods/ resale value etc. }\end{array}$ & $\begin{array}{l}\text { The group look for a site and explore ways of raising money } \\
\text { (whether conventional finance and/or HA partner and/or } \\
\text { gov't. schemes) based on business plan and vision (e.g. may } \\
\text { rule out speculative market model); ends with firm site. }\end{array}$ & $\begin{array}{l}\text { The community association may have sites/property identified } \\
\text { within the public asset register (e.g. empty homes) but } \\
\text { financial and legal complexities still have to be resolved; public } \\
\text { consultation to make case for proposed site and scale of } \\
\text { housing need. }\end{array}$ \\
\hline Stage four & $\begin{array}{l}\text { Project planning gets underway including land acquisition, } \\
\text { planning permission, establishing mix of DIY/ working with a } \\
\text { contractor to start construction on-site. }\end{array}$ & $\begin{array}{l}\text { Project planning gets underway including land acquisition, } \\
\text { planning permission, establishing mix of DIY/ working with a } \\
\text { contractor to start construction on-site. Ongoing group } \\
\text { collaboration around vision of building/living differently for } \\
\text { impact (e.g. ecology, sharing, community outreach). }\end{array}$ & $\begin{array}{l}\text { Project planning gets underway including land acquisition, } \\
\text { planning permission and submissions to government funding } \\
\text { schemes (requires evidence of community engagement); may } \\
\text { team up with a Registered Housing Provider to meet the } \\
\text { criteria for affordable homes subsidy/allocations via waiting } \\
\text { list. }\end{array}$ \\
\hline Stage five & $\begin{array}{l}\text { Construction work continues through to building completion. } \\
\text { This stage concludes when all outstanding permissions and } \\
\text { development requirements are complete. }\end{array}$ & $\begin{array}{l}\text { Construction work continues through to building completion. } \\
\text { The group will be refining agreements and policies (typically by } \\
\text { consensus) on shared assets and responsibilities. This stage } \\
\text { concludes when all outstanding permissions and development } \\
\text { requirements are complete; members can move in. }\end{array}$ & $\begin{array}{l}\text { Construction work continues through to building completion. } \\
\text { Standard tenancy agreements will be drawn up by the } \\
\text { Registered Housing Provider. This stage concludes when all } \\
\text { outstanding permissions and development requirements are } \\
\text { complete; tenants can move in. }\end{array}$ \\
\hline Stage six & $\begin{array}{l}\text { The individual/household moves in. This may be the first } \\
\text { opportunity this new resident has to develop relations with } \\
\text { immediate neighbours and begin to participate in wider } \\
\text { community life. }\end{array}$ & $\begin{array}{l}\text { The group move in, vacant units are being filled or marketed; } \\
\text { the community has begun its established life in the project } \\
\text { that they designed/built for themselves. }\end{array}$ & $\begin{array}{l}\text { Tenants move in. Repair and maintenance arrangements are } \\
\text { put in place. Tenants may be encouraged to form/join a tenant } \\
\text { association. }\end{array}$ \\
\hline Outcomes & $\begin{array}{l}\text { Custom built for individual user. } \\
\text { Personal sense of achievement. } \\
\text { Novel construction methods may increase local contractor } \\
\text { capacity and inspire others, e.g. as 'early adopter' of smart } \\
\text { technologies. }\end{array}$ & $\begin{array}{l}\text { Custom built for e.g. reducing consumption of energy, white- } \\
\text { goods, cars etc., supportive to the needs of younger and older } \\
\text { residents. Collective self-governance (social capital). Social } \\
\text { change } \& \text { novel architecture; may engage in public education } \\
\text { as a 'beacon project'. }\end{array}$ & $\begin{array}{l}\text { Ready-made to fulfil recognised housing need (defined by } \\
\text { affordability as well as age-related infrastructure). Providing } \\
\text { for local housing needs adds value to the wider community } \\
\text { (support for local shops and services). Likely to inspire growth } \\
\text { in the sector as beacon project }\end{array}$ \\
\hline
\end{tabular}


References

Alexander, C. (1977) A Pattern Language: Towns, Buildings, Construction. New York: Oxford University Press.

Amin, A. (2005) Local community on trial. Economy and Society, 34:4, pp.612-633.

Argent, N. (2005). The neoliberal seduction: governing-at-a-distance, community development and the battle over financial services provision in Australia. Geographical Research, 43(1), 29-39.

Ball, M. (2004) Co-operation with the community in property-led urban regeneration, Journal of Property Research, 21:2, pp. 119-142.

Benson, M. (2012) Creating a nation of selfbuilders: an interim report from the project Selfbuilding: the production and consumption of new homes from the perspective of households. London: Goldsmiths (accessed online: 20/09/2014)

BSHF (2011) Self-Help Housing: Supporting Locally Driven Housing Solutions. Windsor: Building and Social Housing Foundation.

BSHF (2014) Community-led housing. Making it happen. London: Building and Social Housing Foundation.

Carp, J. (2011). "The Study of Slow" in Bruce E. Goldstein, ed., Collaborative Resilience: Moving from Crisis to Opportunity, MIT Press, pp. 99-125.

Christian, D. L. (2007) Finding a Community: How to Join and Ecovillage or Intentional Community. Gabriola Island: New Society Publishers.

Clark, S. and Teachout, W. (2012) Slow Democracy: Rediscovering Community, Bringing Decision Making Back Home. New York: Chelsea Green Publishing.

Commission on Co-operative and Mutual Housing (2009) Bringing Democracy Home, London: CCMH.

Chatterton, P. (2015) Low Impact Living: A Field Guide to Ecological, Affordable Community Building. London: Earthscan from Routledge.

Chatterton, P. (2013). Towards an Agenda for Post-carbon Cities: Lessons from Lilac, the UK's First Ecological, Affordable Cohousing Community. International Journal of Urban and Regional Research, 37(5), 1654-1674.

Chiodelli, F. and Baglione, V. (2014) Living together privately: for a cautious reading of cohousing, Urban Research and Practice, 7.1: pp.20-34.

Clapham, D. and Kintrea, K. (2000) Community-based housing organisations and the local governance debate, Housing Studies, 15.4, pp. 533-559. 
Coates, C. (2001) Utopia Britannica: British Utopian Experiments, 1325-1945. London: Diggers \& Dreamers Publications.

Cochrane, A. (2007). Understanding urban policy: a critical approach. Blackwell.

Community Land Trust (2014) History of CLTs

http://www.communitylandtrusts.org.uk/About-CLTs/History-CLTs (accessed online 26/09/2014).

Coote, A. (2011) Big Society and the new austerity. In Stott, M. (ed) The Big Society Challenge. London: Keystone Development Trust Publications, pp. 82-95.

Davis, J.E. (2010) The Community Land Trust Reader. Cambridge, MA: Lincoln Institute of Land Policy.

Department for Communities and Local Government (2011) A plain English guide to the Localism Bill: Update. London: www.communities.gov.uk

Docherty, I., Goodlad, R. and Paddison, R. (2001) Civic culture, community and citizen participation in contrasting neighbourhoods, Urban Studies, 38.12, pp.2225-2250.

Elwood, S. (2004) Partnerships and participation: reconfiguring urban governance in different state contexts, Urban Geography, 25.8, pp.755-770

Evans, P. (2002) Collective capabilities, culture and Amartya Sen's Development as Freedom, in Studies in Comparative International Development, 37.2, pp.54-60.

Field, M. (2011) Introduction: how far has cohousing in the UK come? in Bunker, S., Coates, C., Field, M. and How, J. (Eds) Cohousing in Britain: A Diggers and Dreamers Review. London: Diggers and Dreamers.

Gooding, J. (2013) An investigation into the potential of community-led initiatives, including CLTs, as an approach to regenerate older or other housing areas experiencing decline or lack of investment. Tees Valley. Unlimited.

Gulliver, K., Handy, C. and Morris, J. (2013) More than Markets: Mutual and Cooperative Housing in the UK. Birmingham: Humancity.

Hardy, D. and Ward, C. (1984) Arcadia For All: The Legacy of the Makeshift Landscape. Nottingham: Five Leaves Publication.

Harvey, D. (2005) A Brief History of Neoliberalism. Oxford: Oxford University Press.

Healey, P. (2007) Urban Complexity and Spatial Strategies: Towards a Relational Planning for Our Times. London: Routledge

Heinonen, S., M. Halonen, L. Daldoss (2006) Slow housing- competitive edge for innovative living environments. Fennia 184:1, 91-104.

Heron, J. (1996) Co-operative Inquiry: Research into the Human Condition. London: Sage. 
Jacobs, J. (1961) The Death and Life of Great American Cities. Harmondsworth: Penguin.

Jacobs, K. and Manzi, T. (2013) New localism, old retrenchment: the 'Big Society', housing policy and the politics of welfare reform, Housing, Theory and Society, 30.1, pp.29-45.

Knevitt, C. and Wates, N. (1987) Community Architecture. London: Penguin.

Knox, P. (2005) Creating Ordinary Places: Slow Cities in a Fast World, Journal of Urban Design, 10:1, 1-11.

Levitas, R. (2013) Utopia as Method: the Imaginary Reconstitution of Society. Basingstoke: Palgrave.

Lietaert, M. (2010) Cohousing's relevance to degrowth theories. Journal of Cleaner Production 18.6, 576-580.

Locality (2011) Localism: The Key Components. Locality. http://locality.org.uk/wpcontent/uploads/Localism-the-key-components.pdf [Accessed 3 September 2014]

London Tenants Federation. (2014) Staying Put: An Anti-Gentrification Handbook for Council Estates in London. London: Just space, SNAG

Lowndes, V. and Pratchett, L. (2012) Local governance under the coalition government: austerity, localism and the 'big society', Local Government Studies, 38.1, pp.21-40.

Maclennan, D. and O’Sulivan, A. (2013) Localism, devolution and housing policy, Housing Studies, 28.4, 599-615.

Mayer, H. and Knox, P. (2006) Slow cities: sustainable places in a fast world. Journal of Urban Affairs, 28.4: 321-334.

Meltzer, G. (2005) Sustainable Community: Learning from the Cohousing Model. Victoria, BC: Trafford.

Miele, M. (2008): Cittaslow: Producing Slowness against the Fast Life. Space and Polity, 12:1, pp135-156.

Moore, T. and McKee, K. (2014) The ownership of assets by place-based community organisations: political rationales, geographies of social impact and future research agendas, Social Policy \& Society, 13:4, pp. 521-533.

Moore, T. and McKee, K. (2012) Empowering local communities? An international review of community land trusts. Housing Studies, 27.2, 280-290.

Moore, T., \& Mullins, D. (2013). Scaling-up or going viral? Comparing self-help housing and community land trust facilitation. Voluntary Sector Review, 4(3), 333-353.

Mullins, D. (2010) Self-help housing: could it play a greater role? Third Sector Research Centre, Working Paper 11. 
McDowell, L. (2004) Work, workfare, work/life balance and an ethic of care, Progress in Human Geography, 28.2, 145-163.

McKee, K. (2009) Empowering Glasgow's tenants through community ownership? Local Economy, 24.4, pp.299-309.

NaSBA (2011) An Action Plan to promote the growth of self-build housing. The report of the Self Build Government-Industry Working Group. London: National Self Build Association.

O'Donovan and Rubbra (2012) Public services, civil society and diseconomies of scale. Locality (accessed online).

Orsi, J. (2011) The Slow Homes Manifesto: Post Growth. Available at http://postgrowth.org/the-slow-homes-manifesto/ (accessed 10 $0^{\text {th }}$ June 2012)

Parkins, W. \& Craig, G. (2006) Slow Living. Oxford, New York: Berg.

Perkins, H. and Thorns, D. (2012) Place, Identity and Everyday Life in a Globalizing World. London: Palgrave.

Power, A. (2011) 'Small is beautiful': can Big Society advocates learn from experience? In Stott, M. (ed) The Big Society Challenge. London: Keystone Development Trust Publications.

Radstrom, S. (2011). A Place-Sustaining Framework for Local Urban Identity: an Introduction and History of Cittaslow. Italian Journal of Planning Practice Vol. I, issue 1 2011,pp. 90

Rigby, A. (1974) Communes in Britain. London: Routledge and Kegan Paul.

Riddoch, L. (2011) Blossom: What Scotland Needs to Flourish. Edinburgh: Luath.

Ring, K. (2013) Self-Made City. Berlin: Jovis.

Sargisson, L. (2010) Cohousing: a utopian property alternative?

(www.psa.ac.uk/journals/pdf/5/2010/1225_1085.pdf; accessed 26 June 2010.

Sennett, R. (2010). Together: The Rituals, Pleasures and Politics of Co-operation. London: Allen Lane.

Skerratt, S. and Hall, C. (2011) Community ownership of physical assets: challenges, complexities and implications, Local Economy, 26.3, pp. 170-81.

Smith, S. (2004) States, markets and an ethic of care. Political Geography. 24.1: 1-20.

Steele, W. (2012) Do We Need a 'Slow Housing' Movement? Housing, Theory and Society, Special Issue: Housing and Demographic Change, Volume 29, Issue 2, pp. 
Vestbro, D.U. (1992) From central kitchen to community cooperation: development of collective housing in Sweden. Open House International. 17.2, 30-38.

Wallace, A. Ford, J. and Quilgars, D. (2013) Build-it-Yourself? Understanding the changing landscape of the UK self-build market. York: Centre for Housing Policy.

Woodin, T., Crook, D. and Carpentier, V. (2010) Community and Mutual Ownership: A Historical Review, York: Joseph Rowntree Foundation.

Wyler, S. (2009) A History of Community Asset Ownership. York: Development Trusts Association.

\section{Web-links}

Cittaslow UK (2014) http://www.cittaslow.org.uk/

CLT UK (2014) http://Communitylandtrusts.org.uk/

UK Cohousing Network (2014) http://www.cohousing.org.uk/ 